Review

\title{
Soil health: looking for suitable indicators. What should be considered to assess the effects of use and management on soil health?
}

\author{
Elke Jurandy Bran Nogueira Cardoso ${ }^{1 *}$, Rafael Leandro Figueiredo Vasconcellos ${ }^{1}$, Daniel Bini ${ }^{1}$, Marina Yumi Horta Miyauchi ${ }^{1}$, \\ Cristiane Alcantara dos Santos ${ }^{1}$, Paulo Roger Lopes Alves ${ }^{1}$, Alessandra Monteiro de Paula², André Shigueyoshi Nakatani ${ }^{1}$, Jamil \\ de Moraes Pereira ${ }^{1}$, Marco Antonio Nogueira ${ }^{3}$
}

IUSP/ESALQ - Depto. de Ciência do Solo, Lab. de Microbiologia do Solo, Av. Pádua Dias, 11, C.P. 09 - 13418900 - Piracicaba SP - Brasil.

2UFPR, R. Pioneiro, 2153, Campus Palotina - 85950-000 Palotina PR - Brasil.

${ }^{3}$ Embrapa Soja, Rod. Carlos João Strass, s/n, C.P. 231 86001-970 - Londrina, PR - Brasil.

*Corresponding author <ejbncard@usp.br>

Edited by: Jussara Borges Regitano/Luís Reynaldo Ferracciú Alleoni

Received June 29, 2012

Accepted February 18, 2013
ABSTRACT: Soil Health refers to the ecological equilibrium and the functionality of a soil and its capacity to maintain a well balanced ecosystem with high biodiversity above and below surface, and productivity. To understand and use soil health as a tool for sustainability, physical, chemical, and biological properties must be employed to verify which respond to the soil use and management within a desired timescale. Attributes with a rapid response to natural or anthropogenic actions are considered good indicators of soil health. Among the physical indicators, soil texture, aggregation, moisture, porosity, and bulk density have been used, while among chemical indicators total $\mathrm{C}$ and $\mathrm{N}$, mineral nutrients, organic matter, cation exchange capacity, among others are well established. However, most of them generally have a slow response, when compared to the biological ones, such as microbial biomass $\mathrm{C}$ and $\mathrm{N}$, biodiversity, soil enzymes, soil respiration, etc., in addition to macro and mesofauna. Thus, a systemic approach based on different kinds of indicators (physical, chemical and biological) in assessing soil health would be safer than using only one kind of attribute. Many human activities have caused desertification, loss of biodiversity, disruption of aggregates, loss of organic matter and nutrients, among others. Today, it is imperious to maintain soil health and productivity with increasing emphasis on reforestation and recuperation of degraded areas through the use of organic amendments, reintroduction of plants, soil fauna and microorganisms. This review focused on an integrative view on indicators of soil health to be used as tools for prediction of sustainability in production systems.

Keywords: land-use, microbial community, soil fauna, soil quality, sustainability

\section{Introduction}

The concerns on the sustainability of agricultural systems have increased recently because the agricultural edges have already expanded near to the maximum all over the world. Feeding seven billion people with environmental sustainability is a challenge for the next generations. In addition, pressures of public opinion and markets on the needs of environmental conservation, especially in the tropical region, claim for keeping forests as reserve of biodiversity, provider of environmental services, and needs for reclamation of degraded lands.

Sustainable agriculture aims at meeting the needs of the present without compromising the productive potential for the next generations. Rational soil use practices must allow economically and environmentally sustainable yields, which will only be reached with the maintenance or recovery of the soil health. Thus, a healthy soil has been defined as "The continued capacity of soil to function as a vital living system, within ecosystem and land-use boundaries, to sustain biological productivity, promote the quality of air and water environments, and maintain plant, animal and human health" (Doran and Safley, 1997). To assess the sustainability of a production system, changes in chemical, physical, and biological properties, and the effects on the soil's capacity to support plant growth and exert environmental functions, must be monitored (Doran and Safley, 1997).

Different land uses and management affect the soil as well as the sustainability of production systems. Tillage systems based on plowing and disking (so-called conventional tillage) in the tropical regions decrease soil organic matter and increase the erosion process, leading to chemical, physical, and biological changes in the soil characteristics that enhance the dependence on external inputs and consequently enhance production costs, causing environmental impacts. On the other hand, less impacting cropping systems like no-tillage and organic farming are much more reliant on biological processes for sustainability (Kaschuk et al., 2010).

Sustainable ecosystems, natural or agricultural, rely on the flux of nutrients across trophic levels, which are mainly intermediated by soil fauna and microorganisms (Chen et al., 2003). Up to $95 \%$ of the nitrogen recirculates in an almost closed soil-plant-microorganisms system in a climax forest (Rosswall, 1976). Nevertheless, after removal of the vegetation and agricultural soil use, the system becomes open and creates an external demand for nutrients caused by harvests, leaching, and erosion (Brussaard et al., 2004). The soil fauna and microbial community are considered critical in any ecosystem, by acting on the decomposition of soil organic 
matter, nutrient cycling, and affecting the soil chemical and physical properties, with direct effects on soil fertility and sustainability. The soil biota is very dynamic and promptly affected by soil use and management or any other disturbance, differently from most chemical and physical properties, which take longer to be changed. That is the reason why the edaphic organisms are good indicators of soil health, especially if the indicator corresponds to ecological processes occurring in soil.

Soil quality definition cannot be generalized for all kinds of soil and soil-use as criticized by Sojka and Upchurch (1999). Thus, indicators of soil quality must be selected according to soil use and management, soil characteristics and environmental circumstances. Therefore, in this review, we discuss the general and most used chemical, physical and, mostly, biological indicators of soil health and also some special applications in case studies under tropical and subtropical conditions, especially in Brazil.

\section{Chemical indicators}

Chemical attributes of soil health are correlated with the capacity to provide nutrients for plants and/or retaining chemical elements or compounds harmful to the environment and plant growth. Soil $\mathrm{pH}$, cation exchange capacity (CEC), organic matter and nutrient levels are the main chemical attributes used in soil health assessment, especially when considering the soil capacity for supporting high yield crops (Kelly et al., 2009). Chemical attributes have been correlated with plant yields and thus the variations of a particular indicator are easily interpreted, and allow a quick improvement of the soil chemical properties by liming and/or fertilization. These soil chemical indicators can also be useful in considering the soil's capacity for sustaining forest production and sustainability, maintaining nutrient cycling, plant biomass and organic matter (Schoenholtz et al., 2000).

Idowu et al. (2008) selected a set of parameters to characterize the soil health among 39 physical, chemical and biological attributes and correlated them with plant growth and yield, in soils under different tillage, rotation and cover cropping, in commercial production fields in New York State, USA. These authors concluded that the most important chemical parameters to be assessed were $\mathrm{pH}$, available $\mathrm{P}, \mathrm{K}, \mathrm{Cu}, \mathrm{Fe}, \mathrm{Mn}$, and $\mathrm{Zn}$. Soil $\mathrm{pH}$ is a key indicator because it correlates directly with nutrient availability/solubility and also affects microbial activity. Thus, assessment of $\mathrm{pH}$ allows to predict the potential for nutrient availability in a given production system (Sousa et al., 2007). However, under native vegetation, especially in the tropics, $\mathrm{pH}$ ranges in a very acidic range (even < 3.5) (Chaer and Tótola, 2007), and nutrients, particularly $\mathrm{P}$ are scarce; nevertheless the ecosystem works properly playing its environmental role.

Soil organic carbon is also a key attribute in assessing soil health, generally correlating positively with crop yield (Bennett et al., 2010). The soil organic carbon af- fects important functional processes in soil like the storage of nutrients, mainly $\mathrm{N}$, water holding capacity, and stability of aggregates (Silva and Sá-Mendonça, 2007). In addition, the soil organic carbon also affects microbial activity. Hence, this is a key component of soil fertility, especially in tropical conditions, which interacts with chemical, physical, and biological soil properties and must be considered in assessments of soil health. Although rarely mentioned, soil organic matter may also have negative effects on soil health. High organic matter contents reduce pesticide efficiency, increasing the frequency of needed applications. Complexation with soluble organic matter facilitates pesticide sorption on organic fractions and transport through soil or groundwater (Sojka and Upchurch, 1999).

Nitrogen is the most required plant nutrient, which is found in several chemical forms in soil (Cantarella, 2007), resulting in a very dynamic behavior. Soil nitrogen has been assessed mainly as mineral $\mathrm{N}$, especially nitrate, organic $\mathrm{N}$ or potentially mineralizable $\mathrm{N}$, as stored in the soil organic matter. Despite the importance in plant nutrition and environment, the use of nitrogen as parameter for assessing soil health is subjected to factors that affect its dynamics in soil, like climatic conditions, turning inadequate the diagnosis of the real availability for plants, based on soil chemical analysis (Cantarella, 2007).

Phosphorus $(\mathrm{P})$ is also a key nutrient for agricultural yields and is essential in assessments of soil quality. Along with nitrogen, $\mathrm{P}$ is the main nutrient that limits the agricultural yields in tropical soils, especially in highly weathered, oxidic soils, where the major part of the total soil $\mathrm{P}$ is fixed in clay minerals and oxides. The available $\mathrm{P}$ in the soil solution is present as orthophosphates, but the microbial $\mathrm{P}$ and organic- $\mathrm{P}$ are also stocks that can rapidly become available. Procedures for assessment of $\mathrm{P}$ availability have been well established (Pankhurst et al., 2003; Zhang et al., 2006a).

Soil chemical parameters have been traditionally used for assessment of potentially available nutrients for crops, and are based on worldwide well established analytical methodologies. Among them, organic matter, $\mathrm{pH}$, and available nutrients and also some potential hazardous chemicals have been used to establish levels of soil health. These procedures do not fulfill the promises to help us to understand all factors associated to sustainability, especially in relation to ecological processes. For example, Melo and Marchiori (1999) reported very good levels of chemical indicators in a field cropped with cotton, but the biological indicators were far below the ones found in a native forest used as reference. Thus, the integration among indicators seems to be a more appropriate approach to assess soil health.

\section{Physical indicators}

Physical indicators of soil health generally include simple, fast and low-cost methodologies. Moreover, such indicators like texture, bulk density, porosity, and ag- 
gregate stability are also correlated with hydrological processes like erosion, aeration, runoff, infiltration rate, and water holding capacity (Schoenholtz et al., 2000). In general, a soil is considered physically poor when it shows low rates of water infiltration, enhanced surface runoff, poor cohesion, low aeration and root density, and difficulty for mechanization (Dexter, 2004).

Soil texture is an important factor affecting the balance between water and gases, but it is very stable along time, independently on the soil management. Therefore, bulk density and total porosity can better represent the effects of soil use and management on the water/air relationships (Beutler et al., 2002).

Lower bulk densities have been generally observed in soils under less anthropogenic interferences like native forests (Bini et al., 2013), where the greater levels of soil organic matter permit a better aggregation of soil particles, improving the soil structure. As a result, an increase in soil macroporosity improves the soil permeability not only for water, but also for air and roots (Tejada et al., 2006).

The total soil porosity can be classified as textural, depending on the proportion of soil particles, and structural, depending on biopores and as macro-structure. The second one is easily affected by soil use and management (Dexter, 2004), which may change the characteristic soil water retention curve based on structural pores (For further details, see Dexter, 2004).

The structure corresponds to the arrangement of the primary soil particles (sand, silt and clay) and is affected by the cropping methods and compaction (Dexter, 2004). The granular structure is considered the most suitable for plant growth, allowing for a better balance between macro and micropores, and consequently, between the air/water proportion. Structure is the major soil physical attribute affected by organic matter, and as a consequence other physical characteristics such as porosity, bulk density, aeration, water infiltration and retention, are also affected.

Soil aggregates are formed by particles smaller than $0.2 \mu \mathrm{m}$ that group to form microaggregates $120-250$ $\mu \mathrm{m})$, and microaggregates are grouped to form macroaggregates (Figure 1). Microaggregates are more stable and less affected by soil use and management. In addition, they are responsible for long-term stabilization of soil organic carbon (Six et al., 2004). On the other hand, macroaggregates are more susceptible to the soil use and management, and are especially related to the dynamics of the soil organic matter (Six et al., 2004). The dispersion of soil aggregates under intensive management is usually less severe than in soils with more inputs of organic matter, which results in greater microbial activity (Qin et al., 2010). On the other hand, the decrease of soil organic matter followed by dispersion of aggregates reduces the macroporosity and the soil oxygenation, and impairs the performance of decomposing microbiota and their access to the organic material (Degens et al., 2000; Tejada et al., 2006; Chodak and Niklinska, 2010).
In particular, soil carbohydrates account for 5-25\% of the soil organic matter and also act as stabilizers of the soil aggregates (Spaccini et al., 2001).

Soil aggregates affect aeration, permeability, nutrient cycling, and serve as refuge for microorganisms and soil fauna in microsites. By turn, the soil biota (microorganisms, fauna, and plants) affects the soil aggregates. Many organic substances as secretions, mucilages, mucigels, and cell lysates act as cementing substances produced by several organisms as earthworms, as representatives of soil fauna (Figure 2-A), arbuscular mycorrhizal fungi (Figure 2-B), bacteria (Figure 2-C) and also the plants (Figure 2-D), in addition to their stimulation of microbial activity and action on soil aggregation (Preston et al., 2001).

Organic matter and biological attributes shape the soil physical structure and consequently the hydrological processes (erosion, drainage, runoff, and infiltration rate). In addition, they are fundamental for water and nutrients supply in soil. Humic substances increase the soil capacity for water retention due to charges in their carboxylic and phenolic groups which attract the water molecule and thus reduce its percolation through the soil profile.

As the content of available water is a determining factor of the microbial activity in soil, the soil physical attributes affecting water availability and aeration will also affect the soil microbial activity, since the inverse correlation between water availability and microbial activity has been described before (Geisseler et al., 2011). Thus, the impairment of soil microbial activity due to water limitations can lead to losses of soil functionalities like synthesis and mineralization of soil organic matter and consequent effects on the biogeochemical cycles. Nevertheless, different microbial groups are differently affected by water restrictions in soil. For example, bacteria have restricted movement in drier soils in which

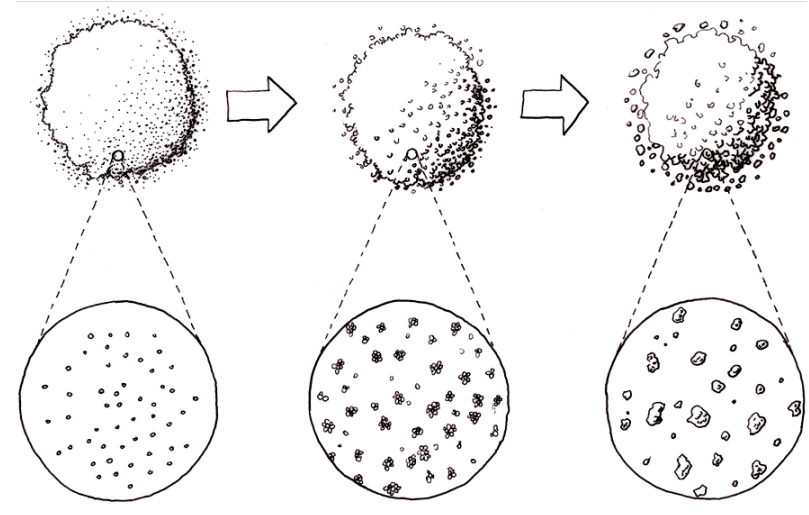

Figure 1 - Formation of soil aggregates: non aggregated soil (left), flocculation (center), that consists in the approximation of the soil particles, and cementation (right), that results from the direct interaction with soil organisms under influence of the soil organic carbon (By M.Y.H. Miyauchi). 


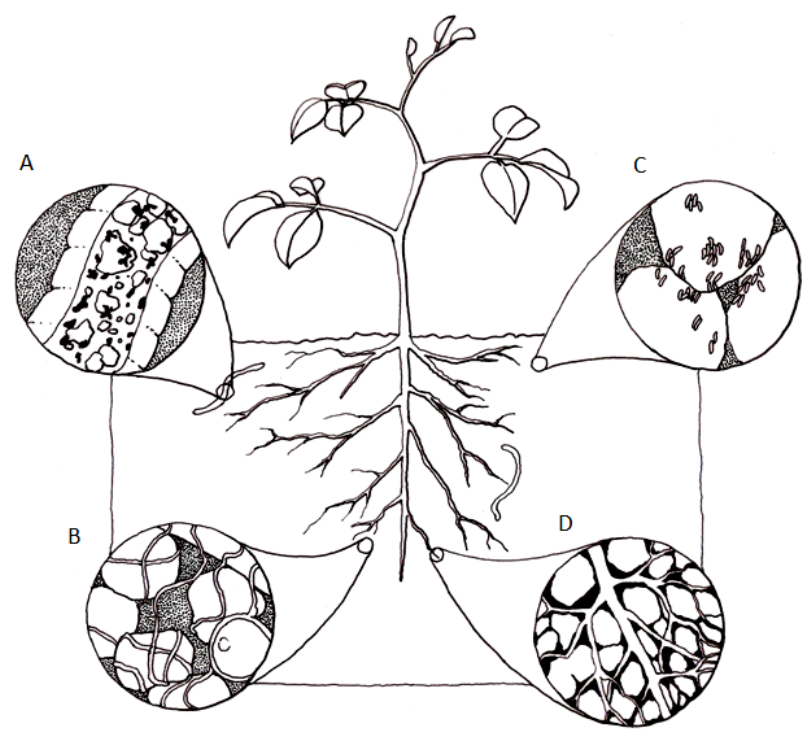

Figure 2 - Contribution of organisms to formation of soil aggregates: earthworms by joining soil mineral particles and organic matter in the intestinal tract (A), arbuscular mycorrhizal fungi with glomalin production (B), bacteria with exopolysaccharides (C), and plants, by action of roots and their exudates (D) (By M.Y.H. Miyauchi).

the water film is more intensively interacting with the soil particles (Wong and Griffin, 1976). Conversely, fungi are favored under drier conditions, in which their hyphae explore the air-filled soil pores. Water availability in soil will depend not only on physical properties like permeability, bulk density, texture, but also on chemical properties like salinity and organic carbon content, in addition to the climatic regime.

In summary, physical soil attributes and soil microbial communities are co-influenced (Degens et al., 2000), and both are affected by soil organic matter.

\section{Biological Indicators}

Understanding the complex interrelationships between biological, physical, and chemical components can be better achieved when studying the origins of natural processes and their fate in nature. For example, by means of photosynthesis, plants fix and transfer carbon as carbohydrates to the food web, which is the most important biological process on earth. Along their lifecycle and especially at the end, animal and plant debris are constantly deposited into the soil. Organic carbon and immobilized minerals must be recycled in the ecosystem before being utilized by new organisms in a continuous and sustainable life-cycle (Schjønning et al., 2004). Thus, biological processes are essential for keeping the soil capacity for recycling carbon to the atmosphere and assure the continuance of photosynthesis, concomitantly with nutrient mineralization for plant and microbial nutrition. Healthy soils have the capacity to keep these processes working in a sustainable way indefinitely.

\section{Microbiological and biochemical indicators}

Soil microbial activity and diversity play important roles in the sustainability by keeping essential functions in soil health, involving carbon and nutrient cycling (Jeffries et al., 2003; Izquierdo et al., 2005). Microbial indicators are more susceptible than physical and chemical attributes to changes imposed to the environment like soil use and management (Melo and Marchiori, 1999; Masto et al., 2009), and for this reason can early forecast any disturbance in the sustainability of an environment.

The soil microbial biomass is the living part of the soil organic matter, formed by fungi, bacteria, protozoa, and algae, and represents an important source of nutrients that may supply plant demands due to its rapid cycling (Sicardi et al., 2004), being one of the main biological attributes used in soil health studies.

In addition to microbial biomass, soil respiration has been widely used as bioindicator of soil health in either forestry or agricultural soils (Bastida et al., 2008). Changes in vegetation like deforestation reduce the microbial respiration in the long-term (Bastida et al., 2006) due to decrease in organic carbon inputs into the soil via surface or rhizosphere (Bini et al., 2013). In agricultural systems, the soil management affects the microbial activity, and in general, the less impacting managements result in higher microbial activity (Balota et al., 2003; Babujia et al., 2010). In this scenario, the organic matter modulates the biological activity as source of $\mathrm{C}$, energy and nutrients that will be mineralized to $\mathrm{CO}_{2}$ and minerals. However, the mineralization rate will also depend on the quantity and quality of the organic material in soil (Zhang et al., 2006b). Simultaneously, the microbial biomass will immobilize $\mathrm{C}, \mathrm{N}, \mathrm{P}$ and other nutrients that can be easily released for plant use due to its rapid turnover (Bayer and Mielniczuk, 2008).

The metabolic quotient $\left(q \mathrm{CO}_{2}\right)$ is an index given by the amount of $\mathrm{CO}_{2}-\mathrm{C}$ released per unit of microbial biomass in time and represents the metabolic status of the soil microorganisms (Anderson and Domsch, 1993), in which higher indices indicate more stressing conditions. However, caution must be taken while interpreting the $q \mathrm{CO}_{2}$ indexes, because higher values might not only be attributed to microbial stress, but also to inputs of easily degradable organic carbon that promptly stimulates the microbial activity (Dinesh et al., 2003).

Soil microorganisms can be classified into functional groups according to the biological process they play in an ecosystem. All microorganisms that act in the $\mathrm{N}$ cycle (e.g., diazotrophic, nitrifying, denitrifying, ammonifying and proteolytic bacteria, etc.) and C cycle (e.g., cellulolytics, amilolytics, proteolytics, etc.) are examples of functional groups. In this case, the individual species is not the focus, but the function they play collectively in an environment. A summary of microbial indicators related to the cycle in which they act and the functions they play is shown (Table 1). 
Table 1 - Microbial indicators of soil quality. The role they play in the soil cycles, and methods for assessment.

\begin{tabular}{|c|c|c|c|}
\hline Indicator & Cycle & Function & Measurement \\
\hline Microbial Biomass & $\begin{array}{l}\text { Mainly } \mathrm{C} \text {, but also } \mathrm{N} \\
\text { and } \mathrm{P}\end{array}$ & Source and/or drain of $\mathrm{C}$ and nutrients & $\mathrm{C}$ and nutrient stocks in cells \\
\hline Soil Respiration & C & Microbial mineralization of organic carbon & $\mathrm{CO}_{2}-\mathrm{C}$ evolution \\
\hline $\mathrm{qCO}_{2}$ index & C & Metabolic condition of the microbial community & $\begin{array}{l}\text { Amount of } \mathrm{C}_{-}-\mathrm{CO}_{2} \text { released per unit of } \\
\text { microbial biomass in time }\end{array}$ \\
\hline Microbial functional groups & $C, N, P$, etc. & $\begin{array}{l}\text { proteolytics, cellulolytics, amilolytics, proteolytics, } \\
\text { phosphate solubilizers and diazotrophic, nitrifying, } \\
\text { denitrifying and ammonifying bacteria. }\end{array}$ & $\begin{array}{c}\text { Colony forming units (CFU) or most } \\
\text { probable number (MPN) on specific or } \\
\text { selective media }\end{array}$ \\
\hline PCR-DGGE & All & Genetic diversity & $\begin{array}{l}\text { DNA extraction, amplification and } \\
\text { separation }\end{array}$ \\
\hline PLFA-profiling & All & Diversity and biomass & $\begin{array}{c}\text { Fatty acids extraction and quantifica- } \\
\text { tion }\end{array}$ \\
\hline Biolog & All & Metabolic diversity & Matabolization of different $C$ sources \\
\hline
\end{tabular}

A soil with high microbial diversity has more chance to keep the ecological processes after a disturbance (Kennedy, 1999). Such capacity is defined as resilience which means a biological buffering against disturbances in an ecosystem. We may usually state that the functional redundancy is higher in less degraded soils (Harris, 2003), but the composition of the plant community may favor the prevalence or cause suppression of certain microbial functional groups in soil (Matsumoto et al., 2005).

Besides microbial activity and biomass, biochemical indicators such as soil enzymes can also be useful indicators of soil health (Table 2). They are involved in several metabolic processes and are also responsive to changes in soil use and management (Nannipieri et al., 2002; Acosta-Martínez et al., 2007). Enzymes are catalysts in different reactions during carbon and nutrient cycling in soil (Balota et al., 2004; Sicardi et al., 2004), and also represent the metabolic level of the soil microbial community. They may be free in soil as exoenzymes excreted by plants, animals, and mainly microorganisms (Weaver et al., 1994), linked to cell structures or internally in cells, but later released to the soil after cell lysis and death (Badiane et al., 2001). Hence, when the soil microbial community is affected due to soil use and management, changes in soil enzyme activities are also expected (Nayak et al., 2007).

The main limitation of using individual biochemical properties as indicators of soil quality is that they show a high degree of variability in response to climate, season, geographical location and pedogenetic factors. This might result in contradictory conclusions in different studies when describing the effects of a contaminant or a given management on the soil quality (Gil-Sotres et al., 2005). Moreover, with the knowledge actually available, estimation of soil quality relying only on individual biochemical properties, simple indexes or ratios, cannot be considered reliable. Thus, a minimum data set of biochemical properties capable of describing the complexity of the soil system is required for each situation, and it must be verified whether they are universally valid.
Facing these challenges, the use of multivariate statistical techniques is a useful tool for selecting attributes for assessment of soil health.

Lande-use changes affect the sooil carbon storage and cause changes quantitative and qualitativ

Land-use changes affect the soil carbon storage and cause quantitative and qualitative changes on soil organic matter, and consequently on physical and chemical characteristics that directly affect the soil microorganisms, like humidity, porosity, density, among others (Bayer and Mielniczuk, 2008). Consequently, these alterations will also reflect on the nutrient cycling and availability of nutrients in soil. Different land-use systems like annual and perennial crops, pastures and forests, generate different residues whose dynamics and cycling will also be different due to differences in composition (e.g., $\mathrm{C} / \mathrm{N}$ ratio, cellulose and lignin contents, resins, monoterpenes, tannins etc.). In addition, more intense agricultural practices, with more soil stirring, can also affect the dynamics of organic matter, speeding up the oxidation process and reduce the stable organic matter, and consequently the biological activity. More conservative agricultural practices like notillage and organic farming has been used to attenuate the negative impact on soil health, thus keeping the system more balanced and sustainable.

Besides the classical techniques for assessing the soil biological quality, new approaches have been recently developed and are tools for helping us to understand the changes in soil biological quality. For example, profiling techniques consist of more specific tools that can be used for assessment of variations in the soil microbial community caused by land-use and management (Kennedy and Smith, 1995).

The capacity of using different carbon sources has been evaluated with the BiologEcoplate ${ }^{\circledR}$ method (Garland and Mills, 1991) and allows to look for quantitative and qualitative physiological profiles of the microbial community (Winding et al., 2005). Considering that the metabolic diversity is consequence of the genetic diversity, environmental effects in gene expression, and ecological interaction among different populations 
Table 2 - Biochemical indicators of soil quality and functions played in soil cycles.

\begin{tabular}{lccc}
\hline Enzyme & Cycle & Function & Microorganisms \\
\hline Dehydrogenase & $\mathrm{C}$ & Electron transferences in the respiratory chain in living & cells \\
$\begin{array}{l}\beta \text {-glucosidase } \\
\text { Cellulase, amylase }\end{array}$ & $\mathrm{C}$ & C oxidation & All aerobic \\
$\begin{array}{l}\text { Urease, glutaminase, and } \\
\text { asparaginase }\end{array}$ & $\mathrm{C}$ & Cellulose degradation with release of glucose \\
$\begin{array}{l}\text { Phosphatases } \\
\text { (Acid and alkaline) }\end{array}$ & $\mathrm{N}$ & $\begin{array}{c}\text { Organic N mineralization to } \\
\text { ammonia/ammonium }\end{array}$ & Mainly fungi, but also bacteria \\
Arilsulphatase & $\mathrm{P}$ & Organic phosphorus cycling & Several \\
\hline
\end{tabular}

(Zak et al., 1994), the metabolic profiling can help us to understand changes in soil biological quality caused by anthropogenic activities or other interferences in the environment.

Phospholipids are found in membranes of all living cells and can be used as biomarkers. Phospholipid fatty acid (PLFA) profiling can be used to determine the phenotypic structure of microbial communities based on phylogenetic relations (Zelles, 1999). The PLFA technique has also been used to elucidate different strategies employed by microorganisms to adapt to changes in environmental conditions due to land-use, climatic changes, and disturbances (Kandeler, 2007). Different microbial groups are characterized by fatty acids linked to specific phospholipid esters, and a change in the structure of such communities is characterized by changes in the patterns and composition of the PLFA in soil. Thus, the content of PLFA has been correlated with other measurements of microbial biomass in soil and therefore has been confirmed as a good indicator of changes in the microbial community (Frostegard et al., 1993). In addition, this technique also allows for assessing the physiological status of the soil microbial communities.

The development of methods based on recombinant DNA has represented great advances in the studies of soil biodiversity and microbial ecology (Torsvik et al., 1990), mainly because these methods are not dependent on cultivation in artificial media. Extraction and amplification of a DNA fragment from soil samples by PCR, employing universal or specific primers, followed by different fingerprinting methods like DGGE/TGGE, T-RFLP, ARDRA, RISA (Kirk et al., 2004) or by cloning and sequencing, can be used to analyze the microbial community in time and space.

The profiling techniques are powerful tools, however cannot supply all the information alone, since each of them has intrinsic limitations. These limitations may cast doubts on the true relationship and contribution of the microbial diversity to the concept of soil quality. Thus, polyphasic approaches are indicated to bring complementary information. The arising of novel methods must be considered as a progress and complementary to the traditional methods, not a replacement. A minimal and distinct set of microbiological techniques is required for each situation and type of study to assess soil health.

\section{Faunal indicators}

Recently, more importance has been given to members of soil fauna as indicators of soil health. This group comprises the invertebrate community that lives totally or during at least a phase of the life cycle in the soil (Brown et al., 2009). They play roles in structuring processes of terrestrial ecosystems, fragmentation of plant residues, and establishing relationships at different levels with microorganisms. Therefore, they actively take part in processes that influence the soil properties and quality, and for this reason are good indicators of changes in the soil (Lavelle and Spain, 2001).

As stated above, the decomposition and transformations of organic materials in soil are predominantly carried out by microorganisms (Adl, 2003). Nevertheless, the microbial processes are more effective when the organic material is more accessible, i.e., more fragmented and distributed along the soil profile (Paul, 2007). Hence, the soil fauna is the main responsible for supplying pretransformed organic material to the microorganisms after fragmentation, resulting from their feeding process. Besides increasing the contact surface, the fauna, especially earthworms, promotes a distribution of organic material vertically or horizontally along the soil layers (Kostina et al., 2011).

The faunal activity also affects soil structure due to the aggregation of soil particles, in addition to the microbial effect (Belnap, 2003). Higher stability of soil aggregates has been observed in soil with higher microbial and earthworm biomasses (Mäder et al., 2002). Moreover, the faunal action mixes soil particles and produces galleries, pores, tunnels, and other biological compartments that make the air and water flow easier, which also stimulates the microbial activity (Lavelle et al., 2006). Conversely, soils with low faunal activity show more compaction, which makes difficult the penetration of plant roots (Drewry et al., 2008).

The diversity, abundance, biomass and density of soil fauna has been used as indicator of natural or anthropogenic impacts on terrestrial ecosystems because they are strictly correlated with physical, chemical, and microbiological soil attributes (Decaëns et al., 2004; Eggleton et al., 2005). This is a quite simple, easy, and economical procedure employed for assessment of the taxonomic diversity at order, class or key species level. Soil fauna 
can be classified according to their food preference, mobility, functional diversity, and mainly by size (Swift et al., 1979) (Table 3). The most representative organisms normally studied as indicators of soil health belong to the mesofauna, which lives in soil macropores and spaces in the soil-litter interface, feeding on fungal hyphae and organic matter, and thus taking part in nutrient cycling and soil aggregation (Lavelle and Spain, 2001). Studies under different environmental conditions have shown that some springtail species are good indicators of soil health (Ponge et al., 2003; Baretta et al., 2008). The macrofauna includes bigger soil organisms which sometimes are active in soil functioning (Lavelle et al., 2006).

Changes in the environment may reflect differently on a species, family or functional group composition of the soil faunae (Wink et al., 2005; Lavelle et al., 2006). Using functional groups as bioindicators has been preferred instead of the total species diversity, due to the role they play in biological processes. The presence or absence of a particular species can be crucial for a given process in an ecosystem (Brussaard et al., 1997), as can be seen when a biological process stops when a key species involved disappears (Schjønning et al., 2004). For example, after some earthworm species had disappeared, the organic material accumulated on the soil surface, and thus the individual activity of the species was considered limiting. Despite the existence of other functional groups of organisms, they were not able to replace the role previously played by the earthworm species (Hoogerkamp et al., 1983). Nevertheless, the presence or absence of a certain species may be limiting for an ecosystem functioning (Huston et al., 2000), and thus the richness index should be considered in assessments of soil quality.

Table 3 - Classification of soil faunae according to their size and function (Schjønning et al., 2004).

\begin{tabular}{|c|c|c|c|}
\hline \multirow[b]{2}{*}{ Function } & \multicolumn{3}{|c|}{ Size } \\
\hline & $\begin{array}{l}\text { Micro- } \\
\text { fauna* }\end{array}$ & $\begin{array}{c}\text { Meso- } \\
\text { fauna** }\end{array}$ & $\begin{array}{c}\text { Macro- } \\
\text { fauna }^{* * *}\end{array}$ \\
\hline & $\begin{array}{c}(<0.20 \\
\mathrm{mm})\end{array}$ & $\begin{array}{c}(0.2- \\
2.0 \mathrm{~mm})\end{array}$ & $\begin{array}{l}(>2.0 \\
\mathrm{mm})\end{array}$ \\
\hline Fragmentation of residues & & $x$ & $x$ \\
\hline Stimulate microbial activity & & & $x$ \\
\hline Organic matter/nutrient redistribution & & & $x$ \\
\hline Soil aggregation/biopores & $x$ & $x$ & $x$ \\
\hline Carbon sequestration & & & $x$ \\
\hline $\begin{array}{l}\text { Nutrient cycling, mineralization/ } \\
\text { immobilization }\end{array}$ & $x$ & $x$ & \\
\hline Humification & & $x$ & $x$ \\
\hline Feeding on fungal hyphae & $x$ & $x$ & \\
\hline Opening channels and galleries & & & $x$ \\
\hline Regulate bacterial/fungal populations & $x$ & $x$ & \\
\hline Mixing organic and mineral particles & & & $x$ \\
\hline
\end{tabular}

Despite the quick response of soil fauna to changes in land-use and management, they are also very responsive to seasonality and climatic variations (Sicardi et al., 2004), thus indicating the necessity of a closer monitoring. In addition, the inference of an interpretative value for biological attributes is not an easy task due to the huge amount of influences on soil organisms. For this reason, a compilation of studies in different environments would be interesting, in order to try to establish biological indices of soil quality, similarly to chemical and physical indices already established.

\section{Case Studies}

\section{Indicators of soil health under varying soil tillage systems}

Different soil uses in agricultural systems regarding management, crop rotation, frequency of application or amounts of applied chemicals lead to changes in physical, chemical, and mainly biological soil properties. In this context, the conventional tillage system is considered to be more aggressive because the intensive soil revolving disturbs some attributes associated to soil health, e.g. decrease in organic matter (Grace et al., 1994), loss of structure (Bayer et al., 2001), increased risk of erosion (Volk et al., 2004), in addition to losses of microbial diversity and activity (Gupta et al., 1994). Less aggressive techniques of soil use, like minimum tillage (Sun et al., 2010) and no-tillage (Balota et al., 2003; Babujia et al., 2010) have been identified as less impacting systems of soil management. In general, the no-tillage system, in addition to adequate crop rotation, has shown to improve attributes associated to soil health. A more stable soil temperature and humidity due to the constant soil mulching, greater inputs and maintenance of organic matter, protection against rain drops, thus preventing soil erosion, do stimulate the soil microbial diversity and activity, and consequent enhancement of nutrient cycling (Balota et al., 2003; Babujia et al., 2010; Kaschuk et al., 2010; Peixoto et al., 2010).

One of the main effects of no-tillage is the maintenance of soil structure. The adoption of no-tillage systems in subtropical southern Brazil for 30 years has increased the concentrations of soil organic $\mathrm{C}$ especially at the $0-10 \mathrm{~cm}$ top layer, when compared to the conventional tillage (Babujia et al., 2010). These findings have also been reported from several other geographic regions under temperate and tropical conditions (Melero et al., 2008; Pandey et al., 2010; Sun et al., 2010).

Despite serving as indicator of alterations due to soil use, changes in soil organic $\mathrm{C}$ are usually of longterm effect. Thus, more promptly responsive attributes must be used to monitor changes in soil attributes caused by anthropogenic effects. In this particular, the soil microbial biomass has been used as a promising indicator of soil health due to its rapid response to changes in soil use and management (Nogueira et al., 2006). Under tropical conditions, increases in $\mathrm{C}$ and $\mathrm{N}$ microbial 
biomasses under no-tillage have been observed mainly at $0-10 \mathrm{~cm}$ of soil depth (Babujia et al., 2010; Balota et al., 2003; Silva et al., 2010). Soil microbial biomass is affected not only by the soil management system, but also by the composition of plant species in the crop rotation system (Silva et al., 2010).

Under semiarid conditions and different tillage systems (disk ploughing, animal-drawn ploughing and minimum tillage) in Mexico, the soil microbial biomass carbon and organic carbon were identified as a minimum data set as potential indicators for soil health assessment (along with soil $\mathrm{pH}$ and exchangeable $\mathrm{Mg}^{2+}$ ) in Agave angustifolia plantations, showing that these soil attributes are closely related and capable of distinguishing the sites and their associated tillage systems (Bautista-Cruz et al., 2011).

Under temperate conditions, comparisons between conventional, minimum, and no-tillage soil management showed no differences among the total microbial biomass based on phospholipids profiling (FAME) techniques (Sun et al., 2010). Nevertheless, when fungal and bacterial biomasses were assessed separately, only the fungal biomass had been favored under the more conservationist soil management. The favoring of fungal biomass can be explained by the maintenance of the hyphal net in the system in which the soil is less revolved (Frey et al., 1999). On the other hand, under more aggressive, stressing conditions, as generally observed under conventional tillage, the bacterial community prevailed in relation to the fungal community (Pankhurst et al., 2002). Thus, it is not rare to find general increase of microbial biomass in soil under notillage in relation to conventional tillage (Helgason et al., 2010; Muruganandan et al., 2010), especially under tropical conditions, where the microbial biomass is greater and activity is more intense (Kaschuk et al., 2010).

Higher enzyme activities under conservationist systems as compared to conventional tillage were also reported (Melero et al., 2008; Qin et al., 2010) in various countries, including Brazil (Mendes et al., 2003; Balota et al., 2004; Carneiro et al., 2004; Carneiro et al., 2009; Peixoto et al., 2010; Lisboa et al., 2012). In general, higher activities of cellulase and amylase are associated with greater amounts of organic $\mathrm{C}$ at the topsoil layer. On the other hand, enzymes like phosphatase may be inhibited by phosphate fertilizers in a feedback effect (Melero et al., 2008; Peixoto et al., 2010).

Several other soil features have influence on enzyme activity; for example, dehydrogenase correlated negatively with soil $\mathrm{pH}$, but correlated positively with total soil C (Melero et al., 2008). Enhanced dehydrogenase activity has often been observed at the $0-10 \mathrm{~cm}$ layer in soil under no-tillage (Mikanová et al., 2009; Silva et al., 2010; Sun et al., 2010). A stimulation of soil microbial activity is also expected to result in higher general enzyme activities (Nayak et al., 2007), because most of the soil enzymes have microbial origin.
As a result, soil use systems that keep organic material on the soil surface maintain higher levels of soil microbial and biochemical activities, therefore pointing to greater environmental sustainability.

\section{Indicators of soil health in forestry systems}

Most of the forestry environments worldwide have undergone large losses in their floristic composition. Approximately 13 million ha of native forests have been converted into other land use systems or lost by natural disasters according to FAO's biannual report (FAO, 2011). All these changes in natural landscapes have caused loss of biodiversity, and increasing concerns associated to emissions of greenhouse gases and soil degradation.

One of the main concerns regarding conversion of forest into agriculture is the decrease of $\mathrm{C}$ stocks in the soil with transference to the atmosphere as $\mathrm{CO}_{2}$ (Lemenih et al., 2005). Comparing agricultural soil with a reference site under native forest, the $\mathrm{C}$ stocks were 50-75\% less in the agricultural soil (Spaccini et al., 2001). Therefore, it is very easy to lose the soil organic carbon due to soil use and management, but the recovery back to the original levels as found in the native forest is very difficult to be reached (Nogueira et al., 2006). The clear-cut of a Mixedwood (Populus tremuloides-Picea glauca) stand in Central Saskatchewan, Canada, showed no changes in the short-term (1-5 yr) in comparison with the mature forest, but in the medium-term (6-20 yr), soil organic carbon and soil nitrogen decreased by $24 \%$ and $27 \%$, respectively, causing environmental concerns (Pennock and Van Kessel, 1997).

Another important indicator of soil health is the level of soil microbial biodiversity. Environmentally friendly strategies of soil use and management must maintain or increase the soil biodiversity and ultimately preserve the soil ecological functions in the environment. Nevertheless, assessment of soil microbial diversity is not an easy task, because 95-99\% of soil microorganisms are not cultivable on artificial media. Alternative tools independent of cultivation have been based on molecular biology and have brought new insights in studies on soil microbial diversity. For example, the genetic diversity of the ribosomal gene 16S (16s rDNA) for bacteria based on the PCR-DGGE technique (polymerase chain reaction - denaturating gradient gel electrophoresis) showed that sites reforested with native species presented similar bacterial diversity to the soil with native forest. Nevertheless, reforestation with Eucalyptus resulted in less bacterial diversity in soil (Nogueira et al., 2006). Card and Quideau (2010) found similar results and also observed that microbial diversity in soil increased with the time elapsed after reforestation. Vasconcellos et al. (2013) studied microbiological indicators of soil quality in a gradient of riparian forest reclamation in the Brazilian Atlantic forest biome and found that microbial biomass, urease activity and Bacteria community structure followed the recovery process, emphasizing the need for more than $20 \mathrm{yr}$ for the sites to recover the similarities to the native riparian forest. 
The replacement of native forests by exotic species leads to great changes in the soil properties and processes like distribution of the soil organic matter along the soil horizons and on the composition of the soil fauna (Córdova et al., 2009). Reforestation with exotic species of economical interest or conversion to pastures causes deep interferences in the structure and functionality of the ecosystem (Pankhurst et al., 1997). The soil fauna in native fields is more diverse than in reforestations with Pinus taeda, P. elliottii, and Araucaria angustifolia (Córdova et al., 2009). Similar results were found for microbial and biochemical processes related to $\mathrm{N}$ and $\mathrm{C}$-cycling in southern Brazil (Fagotti et al., 2012; Bini et al., 2013), in which reforestation with Pinus showed to impair the microbial processes in soil as compared to reforestation with $A$. angustifolia, emphasizing that different indicators of soil health followed the same trend.

The diversity of springtails decreased in reforestations in comparison with native fields, as the faunal diversity in general (Deharveng, 1996). The intensity of changes in the land-use system may eliminate some species essential for biochemical processes (Kouadio et al., 2009), compromising the sustainability. Studies on abundance, diversity, and structure of the invertebrate community in soil have been useful indicators of soil health in forest environments. Decaëns et al. (2004) observed that conversion of native ecosystems in the Colombian tropical savanna into pastures did not change the taxonomic richness and composition of organisms, while the conversion of Brazilian rainforest caused deep changes in the macrofauna community, including substitution of native earthworms by exogenous species. Even under temperate conditions, the total abundance and species composition decreased with the intensification of land use (Ponge et al., 2003). Similarly, Baretta et al. (2007) reported that the diversity, abundance, and biomass of earthworms in native or reforested Brazil Pine (A. angustifolia) forests were sensitive enough to distinguish the sites under different land-use.

A spruce (Picea abies) forest in the Italian Alps (Salmon et al., 2008) revealed strong changes in composition of organisms and also in soil $\mathrm{C}$ mineralization. Great abundance of mites (Acari) was favored by the recalcitrant plant residue, but there was low density of springtails and absence of several other groups of soil macrofauna. Conversely, during the different successional stages, there was a continuous up and down of several groups of invertebrates. The richness of the soil fauna was greater during the periods of revegetation, when the soil cover consisted of diverse growing trees and abundant herbaceous vegetation. Similar results were obtained by Lucas-Borja et al. (2010) in a study with pine forests.

One of the most important factors affecting biological indicators of soil health in forestry environments is the $\mathrm{C}$ to $\mathrm{N}$ ratio of the plant residues. Thus, changes in the structure of plant community, like conversion of native forest to monocultures, deeply alters the bio- logical indicators of soil health due to changes in the quantity and quality of vegetal residues deposited on the soil surface and directly inside the soil as rhizodeposition (Fagotti et al., 2012; Bini et al., 2013). Thus, the removal of native plant community firstly changes microbial communities and soil fauna, and later also physical-chemical attributes like temperature, water availability, concentration of organic matter, nutrients, pH, etc. As reported by Bautista-Cruz et al. (2012), in a forest recovery study after clearing in Mexico, chemical indicators like $\mathrm{pH}$, plant-available $\mathrm{P}$ and exchangeable $\mathrm{Al}^{3+}$, besides $\mathrm{O}$ horizon thickness, changed extremely slowly, in time spans estimated at 100 yr. Biological indicators, however, are much more sensitive to detect alterations in soil health caused by land-use changes (Wink et al., 2005). In a forestry restoration chronosequence after mining, the increase of soil organic carbon was only $1.7 \%$ after 30 years, and even after 50 years of restoration the ratio between microbial and total carbon did not reach the levels found in the native, reference site (Insam and Domsch, 1988). Substitution of native vegetation by exotic species also decreased the microbial biomass and activity in soil (Rutigliano et al., 2004; Fagotti et al., 2012; Bini et al., 2013). The $\mathrm{C} / \mathrm{N}$ ratio and the recalcitrance of the organic molecules are the main factors to define the availability of organic $\mathrm{C}$ for the soil biota. However, certain soil enzymes may be activated by the presence of certain organic compounds, e.g. cellulase in the presence of cellulose with a high $\mathrm{C}$ to $\mathrm{N}$ ratio (Andersson et al., 2004; Bini et al., 2013).

Assessment of indicators of soil health in different strategies of soil use has shown increase of total organic carbon and ammonification rate in forestry soils (Nogueira et al., 2006). In addition, the $\mathrm{C}$ and $\mathrm{N}$ microbial biomasses in the secondary and artificially reforested sites after 20 years tended to approximate values of the native forest, but in a site under Eucalyptus for 50 years, values were similar to an agricultural fallow site. Assessments of indicators of soil health are particularly important to evaluate the success of a given strategy for reclamation of degraded forestry environments (Bastida et al., 2006; Nogueira et al., 2006). Greater emphasis has been given to biological and biochemical indicators due to their greater sensitivity (Wink et al., 2005). Soil enzyme activities have also been widely employed in forestry soils to assess effects of changes in land use (Bastida et al., 2008; Lucas-Borja et al., 2010; Fagotti et al., 2012; Bini et al., 2013). Despite their high sensitivity to environmental conditions, soil enzymes are also sensitive to seasonal variations. For example, dehydrogenase was the lowest in the autumn due to low temperatures that restricted the soil microbial activities, while the activity of urease was inversely correlated with the concentrations of ammonium in soil when both plants and microorganisms were less active. On the other hand, phosphatase and arylsulphatase were not affected by temperature, but depended on the amount of litter on the soil surface (Kang et al., 2009). 
Assessment of $\mathrm{C}$ and $\mathrm{N}$ microbial biomass, soil respiration and enzyme activities are correlated with the content of soil organic matter and the age of successional stages (Jiang et al., 2009) and are generally lower in agricultural soils when compared to native forests, a fact attributed to less C inputs (Dinesh et al., 2003; Kaschuk et al., 2010; Bini et al., 2013). Additionally, the enzyme activities also correlate with the soil microbial biomass (Jiang et al., 2009). Forest cleaning, cropping and management affect the soil microbial diversity and activity (Degens et al., 2000, Stark et al., 2008). Decrease in microbial activity in intensively managed soil in comparison to well managed pastures has been observed (Riffaldi et al., 2002). In general, the maintenance of soil organic $\mathrm{C}$ is the main factor that favors the microbial activity (Lizarazo et al., 2005).

In natural ecosystems, the rate between input and decomposition of organic material is under dynamic balance, with predominance of mineralization of nutrients. Bastida et al. (2006) observed less microbial and biochemical activities in soils even after 15 years after deforestation and start of the vegetation reestablishment. Similar results were observed in a secondary forest under regeneration for 20 years (Nogueira et al., 2006). In general, the levels of soil organic carbon increase with the vegetation recovery (Jiang et al., 2009; Chodak and Niklinska, 2010; Bautista-Cruz et al., 2012), but this is generally a slow process.

Besides the decreases in the soil organic carbon levels, changes in other physical-chemical attributes also affect the microbial activity in degraded soils. Erosion is one of the main factors affecting the physical soil conditions, in addition to soil compaction and decrease in aggregate stability (Hartanto et al., 2003). The increase of the soil bulk density due to traffic of machines or animals and the loss of aggregate stability due to decrease in the soil organic carbon directly affect the plant root development and the water and air dynamics within the soil.

As observed, the main causes of changes in diversity and activity of microbial community and fauna in forest soils is the quantity and quality of residues that return to the soil surface, and consequently, the soil organic matter levels. Nevertheless, in order to better understand the effects of use and management on soil health, physical, chemical, and biological attributes should be assessed altogether because they are interconnected and run mutual interferences, although they have different levels of responsiveness to changes.

\section{Indicators of soil health in soils amended with resi- dues}

Residues like cattle, poultry, and pig dung have historically been used in agricultural soils. Besides acting as source of nutrients, notably nitrogen and phosphorus, animal residues also contribute to improve soil physical and chemical properties (Haynes and Naidu, 1998).
Nowadays, several industrial and urban residues have also been applied as alternative sources of nutrients in agriculture, but many times without the appropriate studies on their potential environmental impacts. Due to its capacity for cycling a large sort of residues, soil has been seen as the receiving end of residues produced by several activities. Nevertheless, depending on the nature and amount of residues, the soil's biological capacity for recycling may be exceeded, leading to soil contamination and interruption of several ecological functions.

Landfarming aiming at microbial degradation of the organic fraction of petrochemical residues is an example of soil use as an efficient bioreactor (Dua et al., 2002; Tyagi et al., 2011). Nevertheless, presence of heavy metals, salts and recalcitrant compounds sometimes leads to reduction of soil microbial activity. Paula et al. (2006) observed that although total microbial biomass, culturable bacteria and fungi were similar among agricultural soils and landfarming of petrochemical residues, the metabolic coefficient $\left(q \mathrm{CO}_{2}\right)$ and activities of $\beta$-glycosidase, acid phosphatase, and urease indicated that the long-term soil use as landfarming could lead to a loss of the soil's capacity to degrade residues.

The use of urban residues in agriculture, like sludge from sewage treatment plants, liquid effluent from treated sludge, and composted domiciliary waste, has two main environmental objectives: nutrient cycling and alternative destination of residues, instead of disposition in sanitary landfills or discharge in surface waters. Moreover, these residues can also be used for reclamation of degraded soils (Tamanini et al., 2008). Due to the general predominance of organic matter, sewage sludge or composted domiciliary wastes increase the soil organic matter, and consequently its water holding capacity and nutrients, and stimulate the soil microbial activity (Oliveira et al., 2002; Betiol and Fernandes, 2004). Nevertheless, the main concerns on the risks of using residues on soil health are the presence of high levels of heavy metals and other organic or inorganic contaminants (Lara et al., 1999). Despite established criteria for application of residues in soil (e.g., USEPA, 1995; CONAMA, 2006), most of them are based on human health, whereas less attention has been given to the potential risks on soil health (Passuello et al., 2010).

The use of urban or industrial residues as irrigation water and also as complementing source of nutrients may represent risks for soil health, depending on its characteristic (Toze, 2006). For this reason, monitoring of biological, chemical and physical indicators of soil health is essential for safer strategies for the application of residues. Fonseca et al. (2007) concluded that irrigation of crops with effluent from treated sewage is economically and environmentally feasible, but the accumulation of sodium in the soil and losses of nitrogen by leaching or volatilization must be regularly monitored to avoid environmental risks. In addition to 
chemical attributes, monitoring microbial activity can also provide essential information on the soil health under a specific management, especially concerning to nutrient cycling (Paula et al., 2010). Thus, the monitoring of soil functions in sites used for receiving residues is essential to prevent the soil degradation. In addition, monitoring of chemical or even biological contaminants is also important to prevent any adverse effect on soil functions and plant growth and health. As a more comprehensive strategy, a pool of indicators can be useful for monitoring the impacts of application of residues on soil health.

\section{Final remarks}

In the Agricultural sphere, an extensive knowledge on soil degradation is already present. All over the world, there are many thousands of $\mathrm{km}^{2}$ of degraded soils, as a consequence of a kind of agriculture whose priority was only high crop productivity. Thus, the excessive use of synthetic fertilizers, the systematic deforestation, soil erosion due to high tillage and the action of rains or winds, loss of organic matter and several other factors brought about increasing desertification, the loss of millions of tons of fertile top soil and, indirectly, silted up rivers and lakes, caused soil salinisation, climate changes and loss of biodiversity.

Besides the need for constant monitoring and evaluations of physical-chemical and biological processes to achieve better soil health, it is imperious to keep in mind that soil microorganisms are the main agents of nutrient cycling and also have a complex interaction with plants. Any land-use strategy that contributes to a better equilibrium of soil microorganisms is able to result in greater crop productivity, at low cost, and contributes to minimize the use of mineral fertilizers or pesticides, favoring high sustainability.

To approach the environmental problems it is necessary to act on various fronts, as: (i) characterize the soils through their hydrodynamic activity, the dynamics of percolating solutions and their retention of different elements; (ii) to monitor available nutrients and augment their efficiency in plant nutrition; (iii) evaluate changes in soil physical and chemical properties; (iv) evaluate quantitative and qualitative changes of soil organic matter due to application of organic residues; (v) evaluate the effects on the soil microbial biomass and its metabolic activities; (vi) evaluate plant productivity and nutritional status; (vii) investigate the sustainability of the system and its relative dependence on sanitary, technical, and economic aspects.

New research lines must be implemented, and one of them is the need for a concentrated effort in organic composting. It is fundamental to convince the institutions responsible for regulation and control of the wellbeing of the environment, as well as the federal, state or municipal governments to apply these methods to achieve a satisfactory solution for a sanitary treatment of polluting materials, avoiding environmental contamination of rivers, soil and atmosphere and minimizing the production of greenhouse gases, thereby giving back to the soil over $90 \%$ of the organic materials today being considered useless trash. Another decisive point is the development of processes and methodologies to study ecotoxicological aspects of all kinds of residues, independently of origin, creating an interface with human health. Undoubtedly, we can claim that public health depends on healthy food, and this, in turn, is directly linked to the soil health. Finally, soil health is the first requirement for agricultural and environmental sustainability.

\section{References}

Acosta-Martínez, V.; Cruz, L.; Sotomayor-Ramírez, D.; PérezAlegría, L. 2007. Enzyme activities as affected by soil properties and land use in a tropical watershed. Applied Soil Ecology 35: 35-45.

Adl, S.M. 2003. The Ecology of Soil Decomposition. Cromwell Press, Trowbridge, UK.

Anderson, T.H.; Domsch, K.H. 1993. The metabolic quotient from $\mathrm{CO}_{2}\left(q \mathrm{CO}_{2}\right)$ as a specific activity parameter to assess the effects of environmental conditions, such as $\mathrm{pH}$, on the microbial biomass of forest soils. Soil Biology and Biochemistry 25: 393-395.

Andersson, M.; Kjøller, A.; Struwe, S. 2004. Microbial enzyme activities in leaf litter, humus and mineral soil layers of European forests. Soil Biology and Biochemistry 36: 15271537.

Babujia, L.C.; Hungria, M.; Franchini, J.C.; Brookes, P.C. 2010. Microbial biomass and activity at various soil depths in a Brazilian oxisol after two decades of no-tillage and conventional tillage. Soil Biology and Biochemistry 42: 21742181.

Badiane, N.N.Y.; Chotte, J.L.; Pate, E.; Masse, D.; Rouland, C. 2001. Use of soil enzyme activities to monitor soil quality in natural and improved fallows in semi-arid tropical regions. Applied Soil Ecology 18: 229-238.

Balota, E.L.; Colozzi-Filho, A.; Andrade, D.S.; Dick, R.P. 2003. Microbial biomass in soils under different tillage and crop rotation systems. Biology and Fertility of Soils 38: 15-20.

Balota, E.L.; Kanashiro, M.; Colozzi Filho, A.; Andrade, D.S.; Dick, R.P. 2004. Soil enzyme activities under long-term tillage and crop rotation systems in subtropical agro-ecosystems. Brazilian Journal of Microbiology 35: 300-306.

Baretta, D.; Brown, G.G.; James, S.W.; Cardoso, E.J.B.N. 2007. Earthworm populations sampled using collection methods in Atlantic Forests with Araucaria angustifolia. Scientia Agricola 64: 384-392.

Baretta, D.; Maluche-Baretta, C.R.D.M.; Cardoso, E.J.B.N. 2008. Multivariate analysis of soil microbiological and chemical attributes in forests with Araucaria angustifolia. Revista Brasileira de Ciência do Solo 32: 2683-2691 (in Portuguese, with abstract in English).

Bastida, F.; Moreno, J.L.; Hernández, T.; García, C. 2006. Microbiological activity in a soil 15 years after its revegetation. Soil Biology and Biochemistry 38: 2503-2507. 
Bastida, F.; Zsolnay, A.; Hernández, T.; García, C. 2008. Past, present and future of soil quality indices: a biological perspective. Geoderma 147: 159-171.

Bautista-Cruz, A.; Del Castillo, R.F.; Etchevers-Barra, J.D.; Gutiérrez-Castorena, M.C.; Báez, A. 2012. Selection and interpretation of soil quality indicators for forest recovery after clearing of a tropical montane cloud forest in Mexico. Forest Ecology and Management 277: 74-80.

Bautista-Cruz, A., de León-González, F., Carrillo-González, R., Robles, C. 2011. Identification of soil quality indicators for maguey Mezcalero (Agave angustifolia Haw.) plantations in southern Mexico. African Journal of Agricultural Research, 6: 4795-4799.

Bayer, C.; Martin-Neto, L.; Mielniczuk, J.; Pillon, C.N.; Sangoi, L. 2001. Changes in soil organic matter fractions under subtropical no-till cropping systems. Soil Science Society American Journal 65: 1473-1478.

Bayer, C.; Mielniczuk, J. 2008. Dinâmica e função da matéria orgânica $=$ Organic matter dynamics and function. p. 7-18. In: Santos, G.A.; Silva, L.S.; Canellas, L.P.; Camargo, F.A.O., eds. Fundamentos da matéria orgânica do solo: ecossistemas tropicais e subtropicais $=$ Fundamentals of soil organic matter: tropical and subtropical ecosystems. Ed. Metrópole, Porto Alegre, RS, Brazil. (in Portuguese).

Belnap, J. 2003. The world at your feet: desert biological soil crusts. Frontiers in Ecology and the Environment 1: 181-189.

Bennett, L.T.; Mele, P.M.; Annett, S.; Kasel, S. 2010. Examining links between soil management, soil health, and public benefits in agricultural landscapes: an Australian perspective. Agriculture, Ecosystems and Environment 139: 1-12.

Betiol, W.; Fernandes, S.A.P. 2004. Efeito do Lodo de Esgoto na Comunidade Microbiana e Atributos Químicos do Solo = Effect of Sewage Sludge on the Soil Microbial Community and Chemical Attributes. Embrapa Solos, Rio de Janeiro, RJ, Brazil. p. 1-6. (Comunicado Técnico, 24). (in Portuguese).

Beutler, A.N.; Centurion, J.F.; Souza Z.M.; Andrioli, I.; Roque, C.G. 2002. Water retention in two oxisols under different uses. Revista Brasileira de Ciência do Solo 26: 829-834 (in Portuguese, with abstract in English).

Bini, D.; Santos, C.A.; Carmo, K.B.; Kishino, N.; Andrade, G.; Zangaro, W.; Nogueira, M.A. 2013. Effects of land use on soil organic carbon and microbial processes associated with soil health in southern Brazil. European Journal of Soil Biology 55: 117-123.

Brown, G.G.; Maschio, W.; Froufe, L.C.M. 2009. Macrofauna do Solo em Sistemas Agroflorestais e Mata Atlântica em Regeneração nos Municípios de Barra do Turvo, SP, e Adrianópolis, $\mathrm{PR}=$ Soil Macrofauna in Agroforestry and Atlantic Forest under Regeneration in the Municipalities of Barra do Turvo, SP, and Adrianópolis, PR. Embrapa Florestas, Colombo, PR, Brazil.. 51 p. (in Portuguese).

Brussaard, L.; Kuyper, T.W.; Didden, W.A.M.; De Goede, R.G.M.; Bloem, J. 2004. Biological soil quality: from biomass to biodiversity: importance and resilience to management stress and disturbance. p. 139-161. In: Schjonning, P.; Elmholt, S.; Christensen, B.T., eds. Managing soil quality: challenges in modern agriculture. $\mathrm{CAB}$ International, Wallingford, UK.
Brussaard, L.; Behan-Pelletier, V.M.; Bignell, D.E.; Brown, V.K.; Didden, W.; Folgarait, P.; Fragoso, C.; Freckman, D.W.; Gupta, V.V.S.R.; Hattori, T.; Hawksworth, D.L.; Klopatek, C.; Lavelle, P.; Malloch, D.W.; Rusek, J.; Söderström, B.; Tiedje, J.M.; Virginia, R.A. 1997. Biodiversity and ecosystem functioning in soil. Ambio 26: 563-570.

Cantarella, H. 2007. Nitrogênio = Nitrogen. p. 375-470. In: Novais, R.F.; Alvarez, V.; Barros, N.F.; Fontes, R.L.F.; Cantarutti, R.B.; Neves, J.C.L., eds. Fertilidade do solo $=$ Soil fertility. Sociedade Brasileira de Ciência do Solo, Viçosa, MG, Brazil. (in Portuguese).

Carneiro, R.G.; Mendes, I.C.; Lovato, P.E.; Carvalho, A.M.; Vivaldi, L.J. 2004. Soil biological indicators associated to the phosphorus cycle in a Cerrado soil under no-till and conventional tillage systems. Pesquisa Agropecuária Brasileira 39: 661-669 (in Portuguese, with abstract in English).

Carneiro, M.A.C.; Souza, E.D.; Reis, E.F.; Pereira, H.S.; Azevedo, W.R. 2009. Physical, chemical and biological properties of cerrado soil under different land use and tillage systems. Revista Brasileira de Ciência do Solo 33: 147-157 (in Portuguese, with abstract in English).

Card, S.M.; Quideau, S.A. 2010. Microbial community structure in restored riparian soils of the Canadian prairie pothole region. Soil Biology and Biochemistry 42: 1463-1471.

Chaer, G.M.; Tótola, M.R. 2007. Impact of organic residue management on soil quality indicators during replanting of eucalypt stands. Revista Brasileira de Ciência do Solo 31: 13811396 (in Portuguese, with abstract in English).

Chen, G.; Zhu, H.; Zhang, Y. 2003. Soil activities and carbon and nitrogen fixation. Research in Microbiology 154: 393-398.

Chodak, M.; Niklinska, M. 2010. Effect of texture and tree species on microbial properties of mine soils. Applied Soil Ecology 46: 268-275.

Conselho Nacional do Meio Ambiente [CONAMA]. 2006. Resolução ${ }^{\circ}$. 375, de 29 de outubro de 2006. Diário Oficial da União, Brasilia, DF, Brazil. (in Portuguese).

Córdova, M.; Chaves, C.L.; Manfredi-Coimbra, S. 2009. Soil fauna $\times$ vegetation: comparative study of diversity edaphic in areas of native vegetation and Pinus sp. stands. Geo ambiente 12: 30-41 (in Portuguese, with abstract in English).

Decaëns, T.; Jiménez, J.J.; Barros, E.; Chauvel, A.; Blanchart, E.; Fragoso, C.; Lavelle, P. 2004. Soil macrofauna communities in permanent pastures derived from tropical forest or savanna. Agriculture, Ecosystems and Environment 103: 301-312.

Degens, B.P.; Schipper, L.A.; Sparling, G.P.; Vojvodic-Vukovic, M. 2000. Decreases in organic $C$ reserves in soils can reduce the catabolic diversity of soil microbial communities. Soil Biology and Biochemistry 32: 189-196.

Deharveng, L. 1996. Soil collembola diversity, endemism, and reforestation: a case study in the Pyrenees (France). Conservation Biology 10: 74-84.

Dexter, A.R. 2004. Soil physical quality Part I. Theory, effects of soil texture, density, and organic matter, and effects on root growth. Geoderma 120: 201-214.

Dinesh, R.; Chaudhuri, S.G.; Ganeshamurthy, A.N.; Dey, C. 2003. Changes in soil microbial indices and their relationships following deforestation and cultivation in wet tropical forests. Applied Soil Ecology 24: 12-26. 
Doran, J.W.; Safley, M. 1997. Defining and assessing soil health and sustainable productivity. p. 1-28. In: Pankhurst, C.E.; Doube, B.M.; Gupta, V.V.S.R., eds. Biological indicators of soil health. CAB International, Wallingford, UK.

Drewry, J.J.; Cameron, K. C.; Buchan, G. D. 2008. Pasture yield and soil physical property responses to soil compaction from treading and grazing: a review. Australian Journal of Soil Research 46: 237-256.

Dua, M.; Singh, A.; Sethunathan, N.; Johri, A.K. 2002. Biotechnology and bioremediation: successes and limitations. Applied Microbiology and Biotechnology 59: 143-152.

Eggleton, P.; Vanbergen, A.J.; Jones, D.T.; Lambert, M.C.; Rockett, C.; Hammond, P.M.; Beccaloni, J.; Marriott, D.; Ross, E.; Giusti, A. 2005. Assemblages of soil macrofauna across a Scottish land-use intensification gradient: influences of habitat quality, heterogeneity and area. Journal of Applied Ecology 42: 1153-1164.

Fagotti, D.S.L.; Miyauchi, M.Y.H.; Oliveira, A.G.; Santinoni, I.A.; Eberhardt, D.N.; Nimtz, A.; Ribeiro, R.A.; Paula, A.M.; Queiroz, C.A.S.; Andrade, G.; Zangaro, W.; Nogueira, M.A. 2012. Gradients in N-cycling attributes along forestry and agricultural land-use systems are indicative of soil capacity for N supply. Soil Use and Management 28: 292-298.

Fonseca, A.F.; Herpin, U.; Paula, A.M.; Victória, R.L.; Melfi, A.J. 2007. Agricultural use of treated sewage effluents: agronomic and environmental implications and perspectives for Brazil. Scientia Agricola 64: 194-209.

Food and Agriculture Organization [FAO]. 2011. State of the World Forests. FAO, Rome, Italy. (Technical Report).

Frey, S.D.; Elliott, E.T.; Paustian, K. 1999. Bacterial and fungal abundance and biomass in conventional and no-tillage agroecosystems along two climatic gradients. Soil Biology and Biochemistry 31: 573-585.

Frostegard, A.; Baath, E.; Tunlid, A. 1993. Shifts in the structure of soil microbial communities in limed forests as revealed by phospholipid fatty-acid analysis. Soil Biology and Biochemistry 25: 723-730.

Garland, J.L.; Mills, A.L. 1991. Classification and characterization of heterotrophic microbial communities on the basis of patterns of community-level sole-carbon-source utilization. Applied and Environmental Microbiology 57: 2351-2359.

Geisseler, D.; Horwath, W.R.; Scow, K.M. 2011. Soil moisture and plant residue addition interact in their effect on extracellular enzyme activity. Pedobiologia 54: 71-78.

Gil-Sotres, F.; Trasar-Cepeda, C.; Leirós, M.C.; Seoane, S. 2005. Different approaches to evaluating soil quality using biochemical properties. Soil Biology and Biochemistry 37: 877887.

Grace, P.R.; Ladd, J.N.; Skjemstad, J.O. 1994. The effect of management practices on soil organic matter dynamics. p. 162170. In: Pankhurst, C.E., ed. Soil Biota. CSIRO Information Services, Melbourne, Australia.

Gupta, V.V.S.R.; Roper, M.M.; Kirkegaard, J.A.; Angus, J.F. 1994. Changes in microbial biomass and organic matter levels during the first year of modified tillage and stubble management practices on a red earth. Australian Journal Soil Research 32: 1339-1354.
Harris, J.A. 2003. Measurements of the soil microbial community for estimating the success of restoration. European Journal of Soil Science 54: 801-808.

Hartanto, H.; Prabhu, H.; Anggoro, S.E.; Widayat, C.A. 2003. Factors affecting runoff and soil erosion: plot-level soil loss monitoring for assessing sustainability of forest management. Forest Ecology and Management 17: 361-374.

Haynes, R.J.; Naidu, R. 1998. Influence of lime, fertilizer and manure applications on soil organic matter content and soil physical conditions: a review. Nutrient Cycling in Agroecosystems 51: 123-137.

Helgason, B.L.; Walley, F.L.; Germida, J.J. 2010. No-till soil management increases microbial biomass and alters community profiles in soil aggregates. Applied Soil Ecology 46: 390-397.

Hoogerkamp, M.; Rogaar, H.; Eijsackers, H.J.P. 1983. Effect of earthworms on grassland on recently reclaimed polder soils in the Netherlands. p. 85-105. In: Satchell, J.E., ed. Earthworm ecology, from Darwin to vermiculture. Chapman and Hall, London, UK.

Huston, M.A.; Aarssen, L.W.; Austin, M.P.; Cade, B.S.; Fridley, J.D.; Garnier,E.; Grime, J.P.; Hodgson, J.; Lauenroth, W.K.; Thompson, K.; Vandermeer, J.H.; Wardle, D.A. 2000. No consistent effect of plant diversity on productivity. Science 289: 1255.

Idowu, O.J.; van Es, H.M.; Abawi, G.S.; Wolfe, D.W.; Ball, J.I.; Gugino, B.K.; Moebius, B.N.; Schindelbeck, R.R.; Bilgili, A.V. 2008. Farmer-oriented assessment of soil quality using field, laboratory, and VNIR spectroscopy methods. Plant Soil 307: 243-253.

Insam, H.; Domsch, K.H. 1988. Relationship between soil organic carbon and microbial biomass in chronosequences of reclamation sites. Microbial. Ecology 15: 177-188.

Izquierdo, I.; Caravaca, F.; Alguacil, M.M.; Hernández, G.; Roldán, A. 2005. Use of microbiological indicators for evaluating success in soil restoration after revegetation of a mining area under subtropical conditions. Applied Soil Ecology 30: 3-10.

Jeffries, P.; Gianinazzi, S.; Perotto, S.; Turnau, K.; Barea, J.M. 2003. The contribution of arbuscular mycorrhizal fungi in sustainable maintenance of plant health and soil fertility. Biology and Fertility of Soils 37:1-16.

Jiang, J.P.; Xiong, Y.; Jiang, H.; Ye, D.; Song, Y.; Li, F. 2009. Soil microbial activity during secondary vegetation succession in semiarid abandoned lands of loess plateau. Pedosphere 19: 735-747.

Kandeler, E. 2007. Physiological and biochemical methods for studying soil biota and their function. p. 53-84. In: Paul, E.A., ed. Soil microbiology, ecology, and biochemistry. Academic Press, Oxford, UK.

Kang, H.; Kang, S.; Lee, D. 2009. Variations of soil enzyme activities in a temperate forest soil. Ecological Research 24: 1137-1143.

Kaschuk, G.; Alberton, O.; Hungria, M. 2010. Three decades of soil microbial biomass studies in Brazilian ecosystems: lessons learned about soil quality and indications for improving sustainability. Soil Biology and Biochemistry 42: 1-13.

Kelly, B.; Allan, C.; Wilson, B.P.; 2009. Soil indicators and their use by farmers in the Billabong Catchment, southern New South Wales. Australian Journal of Soil Research 47: 234-242. 
Kennedy, A.C. 1999. Bacterial diversity in agroecosystems. Agriculture, Ecosystems and Environment 74: 65-76.

Kennedy, A.C.; Smith, K.L. 1995. Soil microbial diversity and the sustainability of agricultural soils. Plant and Soil 170: 75-86.

Kirk, J.L.; Beaudette, L.A.; Hart, M.; Moutoglis, P.; Klironomos, J.N.; Lee, H.; Trevors, J.T. 2004. Methods of studying soil microbial diversity. Journal of Microbiological Methods 58: 169-188.

Kostina, N.V.; Bogdanova, T.V.; Umarov, M.M. 2011. Biological Activity of the Coprolites of Earthworms. Moscow University of Soil Science, Moscow, Russia. p. 18-23. (Bulletin, 66).

Kouadio, K.D.; Doumbia, M.; Jan, K.; Dagnogo, M.; Aidara, D. 2009. Soil/litter beetle abundance and diversity along a land use gradient in tropical Africa (Oumé, Ivory Coast). Sciences and Nature 6: 139-147.

Lara, A.I.; Ferreira, A.C.; Andreoli, C.V.; Pegorini, E.S.; Ilhenfeld, R.G.K. 1999. Uso e Manejo do Lodo de Esgoto na Agricultura $=$ Use and Management of Sewage Sludge in Agriculture. SANEPAR, Curitiba, PR, Brazil. (in Portuguese).

Lavelle, P.; Decaëns, T.; Aubert, M.; Barot, S.; Blouin, M.; Bureau, F.; Margerie, P.; Mora, P.; Rossi, J.P. 2006. Soil invertebrates and ecosystem services. European Journal of Biology 42: 3-15.

Lavelle, P.; Spain, A. 2001. Soil Ecology. Kluwer Academics, Dordrecht, Netherlands.

Lemenih, M.; Karltun, E.; Olsson, M. 2005. Assessing soil chemical and physical property responses to deforestation and subsequent cultivation in smallholders farming system in Ethiopia. Agriculture, Ecosystems and Environment 105: 373-386.

Lisboa, B.B.; Vargas, L.K.; Silveira, A.O.; Martins, A.F.; Selbach, P.A. 2012. Microbial indicators of soil quality in different management systems. Revista Brasileira de Ciência do Solo 36: 45-55 (in Portuguese, with abstract in English).

Lizarazo, L.M.; Jordá, J.D.; Juárez, M.; Sánchez-Andreu, J. 2005. Effect of humic amendments on inorganic $\mathrm{N}$, dehydrogenase and alkaline phosphatase activities of a Mediterranean soil. Biology and Fertility of Soils 42: 172-177.

Lucas-Borja, M.E.; Bastida, F.; Nicolás, C.; Moreno, J.L.; Del Cerro, A.; Andrés, M. 2010. Influence of forest cover and herbaceous vegetation on the microbiological and biochemical properties of soil under Mediterranean humid climate. European Journal of Soil Biology 46: 273-279.

Mäder, P.; Fliessbach, A.; Dubois, D.; Gunst, L.; Fried, P.; Niggli, U. 2002. Soil fertility and biodiversity in organic farming. Science 296: 1694-1697.

Masto, R.E.; Pramod K.; Singh, C.D.; Patra, A.K. 2009. Changes in soil quality indicators under long-term sewage irrigation in a sub-tropical environment. Environmental Geology 56: 12371243.

Matsumoto, L.S.; Martines, A.M.; Avanzi, M.A.; Albino, U.B.; Brasil, C.B.; Saridakis, D.P.; Rampazo, L.G.L.; Zangaro, W.; Andrade, G. 2005. Interactions among functional groups in the cycling of, carbon, nitrogen and phosphorus in the rhizosphere of three successional species of tropical woody trees. Applied Soil Ecology 28: 57-65.

Melero, S.; Vanderlinden, K.; Ruiz, J.C.; Madejon, E. 2008. Long-term effect on soil biochemical status of a Vertisol under conservation tillage system in semi-arid Mediterranean conditions. European Journal of Soil Biology 44: 437-442.
Melo, W.J.; Marchiori JR, M. 1999. Carbon, microbial biomass carbon and enzyme activity of a soil under natural forest, grassland and cotton culture. Revista Brasileira de Ciência do Solo 23: 257-263 (in Portuguese, with abstract in English).

Mendes, I.C.; Souza, L.V.; Resck, D.V.S.; Gomes, A.C. 2003. Biological properties of aggregates from a cerrado oxisol under conventional and no-till management systems. Revista Brasileira de Ciência do Solo 27: 435-443. (in Portuguese, with abstract in English).

Mikanová, O.; Javurek, M.; Šimon, T.; Friedlová, M.; Vach, M. 2009. The effect of tillage systems on some microbial characteristics. Soil and Tillage Research 105: 72-76.

Muruganandan, S.; Israel, D.W.; Robarge, W.P. 2010. Activities of nitrogen-mineralization enzymes associated with soil aggregate size fractions of three tillage systems. Soil Science Society of America Journal 73: 751-759.

Nannipieri, P.; Kandeler, E.; Ruggiero, P. 2002. Enzyme activities and microbial and biochemical processes in soil. p. 1-33. In: Burns, R.G.; Dick, R.P., eds. Enzymes in the environment: activity, ecology and applications. Marcel Dekker, New York, NY, USA

Nayak, D.R.; Babu, Y.J.; Adhya, T.K. 2007. Long-term application of compost influences microbial biomass and enzyme activities in a tropical Aeric Endoaquept planted to rice under flooded condition. Soil Biology and Biochemistry 39: 1897-1906.

Nogueira, M.A.; Albino, U.B.; Brandão-Júnior, O.; Braun, G.; Cruz, M.F.; Dias, B.A.; Duarte, R.T.D.; Gioppio, N.M.R.; Menna, P.; Orlandi, J.M.; Raiman, M.P.; Rampazo, L.G.L.; Santos, M.A.; Silva, M.E.Z.; Vieira, F.P.; Torezan, J.M.D.; Hungria, M.; Andrade, G. 2006. Promising indicators for assessment of agroecosystems alteration among natural, reforested and agricultural land use in southern Brazil. Agriculture, Ecosystems and Environment 115: 237-247.

Oliveira, F.C.; Mattiazzo, M.E.; Marciano, C.R.; Rossetto, R. 2002. Organic carbon, electric conductivity, $\mathrm{pH}$ and CEC changes in a typic hapludox, after repeated sludge application. Revista Brasileira de Ciência do Solo 26: 505-519 (in Portuguese, with abstract in English).

Pandey, C.B.; Chaudhari, S.K.; Dagar, J.C.; Singh, G.B.; Singh, R.K. 2010. Soil N mineralization and microbial biomass carbon affected by different tillage levels in a hot humid tropic. Soil and Tillage Research 110: 33-41.

Pankhurst, C.; Doube, B.M.; Gupta, V.V.S.R. 1997. Biological Indicators of Soil Health. Wallingford, CAB International, UK.

Pankhurst, C.E.; Kirkby, C.A.; Hawke, B.G. 2002. Impact of a change in tillage and crop residue management pratice on soil chemical and microbiological properties in a cereal-producing red duplex soil in NSW, Australia. Biology and Fertility of Soils 35: 189-196.

Pankhurst, C.E.; Magarey, R.C.; Stirling, G.R.; Blair, B.L.; Bell, M.J.; Garside, A.L. 2003. Management practices to improve soil health and reduce the effects of detrimental soil biota associated with yield decline of sugarcane in Queensland, Australia. Soil and Tillage Research 72: 125-137.

Passuello, A.; Mari, M.; Nadal, M.; Schuhmacher, M.; Domingo, J.L. 2010. POP accumulation in the food chain: integrated risk model for sewage sludge application in agricultural soils. Environment International 36: 577-583. 
Paul, E.A. 2007. Soil Microbiology, Ecology, and Biochemistry. Academic Press, Oxford, UK.

Paula, A.M.; Fonseca, A.F.; Cardoso, E.J.B.N.; Melfi, A.J. 2010. Microbial metabolic potential affected by surplus wastewater irrigation in tropical soil cultivated with Tifton 85 Bermuda grass (Cynodon dactylon Pers. X $C$. niemfuensis Vanderyst). Water, Air and Soil Pollution 205: 161-171.

Paula, A.M.; Siqueira, J.O.; Soares, C.R.F.S. 2006. Biomass, microbial activity and mycorrhizal fungi in landfarming soil of petrochemical wastes. Revista Brasileira de Engenharia Agrícola e Ambiental 10: 448-455 (in Portuguese, with abstract in English).

Peixoto, R.S.; Chaer, G.M.; Franco, N.; Reis Junior, F.B.; Mendes, I.C.; Rosado, A.S. 2010. A decade of land use contributes to changes in the chemistry, biochemistry and bacterial community structures of soils in the Cerrado. Antonie van Leeuwenhoek 98: 403-413.

Pennock, D.J.; Van Kessel, C. 1997. Clear-cut forest harvest impacts on soil quality indicators in the mixedwood forest of Saskatchewan, Canada. Geoderma 75: 13-32.

Ponge, J.F.; Gillet, S.; Dubs, F.; Fedoroff, E.; Haese, L.; Souza, J.P.; Lavelle, P. 2003. Collembolan communities as bioindicators of land use intensification. Soil Biology and Biochemistry 35: 813826.

Preston, S.; Wirth, S.; Ritz, K.; Griffiths, B.; Young, I.M. 2001. The role played by microorganisms in biogenesis of soil cracks: importance of substrate quantity and quality. Soil Biology and Biochemistry 33: 1851-1858.

Qin, S.; Hu, C.; He, X.; Dong, W.; Cui, J.; Wang, Y. 2010. Soil organic carbon, nutrients and relevant enzyme activities in particle-size fractions under conservational versus traditional agricultural management. Applied Soil Ecology 45: 152-159.

Riffaldi, R. 2002. Biochemical properties of a Mediterranean soil as affected by long-term crop management systems. Soil and Tillage Research 67: 109-114.

Rosswall, T. 1976. The internal cycle between vegetation, microorganisms and soils. Ecological Bulletin 22: 157-167.

Rutigliano, F.A.; D'Ascolia, R.; Virzo De Santo, A. 2004. Soil microbial metabolism and nutrient status in a Mediterranean area as affected by plant cover. Soil Biology and Biochemistry 36: 1719-1729.

Salmon, S.; Frizzera, L.; Camaret, S. 2008. Linking forest dynamics to richness and assemblage of soil zoological groups and to soil mineralization processes. Forest Ecology and Management 256: 1612-1623.

Schjønning, P.; Elmholt, S.; Christensen, B.T. 2004. Managing Soil Quality: Challenges in Modern Agriculture. CAB International, Wallingford, UK.

Schoenholtz, S.H.; Vam Miegroet, H.; Burger, J.A. 2000. A review of chemical and physical properties as indicators of forest soil quality: challenges and opportunities. Forest Ecology and Management 138: 335-356.

Sicardi, M.; Garcia-Prechac, F.; Frioni, L. 2004. Soil microbial indicators sensitive to land use conversion from pastures to commercial Eucalyptus grandis (Hill ex Maiden) plantations in Uruguay. Applied Soil Ecology 27: 125-133.
Silva, A.P.; Babujia, L.C.; Franchini, J.C.; Souza, R.A.; Hungria, M. 2010. Microbial biomass under various soil- and cropmanagement systems in short- and long-term experiments in Brazil. Field Crops Research 119: 20-26.

Silva, I.R.; Sá Mendonça, E. 2007. Matéria orgânica do solo = Soil organic matter. p. 275-374. In: Novais, R.F.; Alvarez, V.H.; Barros, N.F.; Fontes, R.L.F.; Cantarutti, R.B.; Neves, J.C., eds. Fertilidade do solo $=$ Soil fertility. Sociedade Brasileira de Ciência do Solo, Viçosa, MG, Brazil (in Portuguese).

Six, J.; Bossuyt, H.; Degryze, S.; Denef, K. 2004. A history of research on the link between (micro) aggregates, soil biota, and soil organic matter dynamics. Soil and Tillage Research 79: 7-31.

Sojka, R.E.; Upchurch, D.R. 1999. Reservations regarding the soil quality concept. Soil Science Society of America Journal 63: 1039-1054

Sousa, D.M.G.; Miranda, L.N.; Oliveira, S.A. 2007. Acidez do solo e sua correção $=$ Soil acidity and its correction. p. 205-275. In: Novais, R.F.; Alvarez, V.H.; Barros, N.F.; Fontes, R.L.F.; Cantarutti, R.B.; Neves, J.C. Fertilidade do solo $=$ Soil fertility. Sociedade Brasileira de Ciência do Solo,Viçosa, MG, Brazil (in Portuguese).

Spaccini, R.; Zena, A.; Igwe, C.A.; Mbagwu, J.S.C.; Piccolo, A. 2001. Carbohydrates in water-stable aggregates and particle size fractions of forested and cultivated soils in two contrasting tropical ecosystem. Biogeochemistry 53: 1-22.

Stark, C.H.; Condron, L.M.; O'Callaghan, M.; Stewart, A.; Di, H.J. 2008. Differences in soil enzyme activities, microbial community structure and short-term nitrogen mineralisation resulting from farm management history and organic matter amendments. Soil Biology and Biochemistry 40: 1352-1363.

Sun, B.; Hallett, P.D.; Caul, S.; Daniell, T.J.; Hopkins, D.W. 2010. Distribution of soil carbon and microbial biomass in arable soils under different tillage regimes. Plant and Soil 338: 17-25.

Swift, M.J.; Heal, W.; Anderson, J.M. 1979. Decomposition in Terrestrial Ecosystems. Blackwell Scientific, London, UK.

Tamanini, C.R.; Motta, A.C.V.; Andreoli, C.V.; Doetzer, B.H. 2008. Land Reclamation Recovery with the Sewage Sludge Use. Brazilian Archives of Biology and Technology 51: 843-855.

Tejada, M.; Garcia, C.; Gonzalez, J.L.; Hernandez, M.T. 2006. Organic amendment based on fresh and composted beet vinasse: influence on physical, chemical and biological properties and wheat yield. Soil Science Society of America Journal 70: 900-90.

Torsvik, V.; Goksoyr , J.; Daae, F.L. 1990. High diversity in DNA of soil bacteria. Applied Environmental Microbiology 56: 78-87.

Toze, S. 2006. Reuse of effluent water-benefits and risks. Agricultural Water Management 80: 147-159.

Tyagi, M.; Fonseca, M.M.R.; Carvalho, C.C.C.R. 2011. Bioaugmentation and biostimulation strategies to improve the effectiveness of bioremediation processes. Biodegradation 22: 231-241.

United States Environmental Protection Agency [USEPA]. 1995. Land Application of Sewage Sludge and Domestic Septage. Washington, DC, USA.

Vasconcellos, R.L.F.; Bonfim, J.A.; Andreote, F.D.; Mendes, L.W.; Baretta, D.; Cardoso, E.J.B.N. 2013. Microbiological indicators of soil quality in a riparian forest recovery gradient. Ecological Engineering http://dx.doi.org/10.1016/j.ecoleng.2012.12.067. 
Volk, L.B.S.; Cogo, N.P.; Streck, E.V. 2004. Water erosion influenced by surface and subsurface soil physical conditions resulting from its management, in the absence of vegetal cover. Revista Brasileira de Ciência do Solo 28: 763-774 (in Portuguese, with abstract in English).

Weaver, R.W.; Angle, S.; Bottomley, P.; Bezdicek, D.; Smith, S.; Tabatabai, A.; Wollum, A. 1994. Methods of Soil Analysis. Part 2. Microbiological and Biochemical Properties. Soil Science Society of America, Madison, WI, USA.

Winding, A.; Hund-Rinke, K.; Rutgers, M. 2005. The use of microorganisms in ecological soil classification and assessment concepts. Ecotoxicology and Environmental Safety 62: 230248.

Wink, C.; Guedes, J.V.C.; Fagundes, C.K.; Rovedder, A.P. 2005. Insetos edáficos como indicadores da qualidade ambiental = Soilborne insects as indicators of environmental quality. Revista de Ciências Agroveterinárias 4: 60-71(in Portuguese).

Wong, P.T.W.; Griffin, M. 1976. Bacterial movement at high matric potentials. I. In artificial and natural soils. Soil Biology and Biochemistry 8: 121-126.
Zak, J.C.; Willing, M.R.; Moorhead, D.L.; Wildman, H.G. 1994. Functional diversity of microbial communities: a quantitative approach. Soil Biology and Biochemistry 26: 1101-1108.

Zelles, L. 1999. Fatty acid patterns of phospholipids and lipopolysaccharides in the characterization of microbial communities in soil: a review. Biology Fertility of Soils 29: 111129 .

Zhang, P.; Li, L.; Pan, G.; Ren, J. 2006a. Soil quality changes in land degradation as indicated by soil chemical, biochemical and microbiological properties in a karst area of southwest Guizhou, China. Environmental Geology 51: 609-619.

Zhang, C.; Huang, L.; Luan, T.; Jin, J.; Lan, C. 2006b. Structure and function of microbial communities during the early stages of revegetation of barren soils in the vicinity of a $\mathrm{Pb} / \mathrm{Zn}$ smelter. Geoderma 136: 555-565. 